Попко О. В., к.е.н., доцент (Національний університет водного господарства та природокористування, м. Рівне)

\title{
ЕКСПОРТНИЙ ПОТЕНЦІАЛ ХАРЧОВОЇ ПРОМИСЛОВОСТІ УКРАЇНИ
}

Окреслено пріоритетні напрямки розвитку експортного потенціалу харчової промисловості України. Здійснено аналіз динаміки обсягів виробництва, експорту та імпорту молока і молочної продукції. Проведено SWOT-аналіз вітчизняної молочної промисловості в умовах активізації інтеграційних процесів.

Ключові слова: експортна стратегія України, експортний потенціал харчової промисловості, експорт молочної продукції, оператори ринку.

На сьогодні харчову промисловість віднесено до базових секторів економіки, які формують ВВП України, надходження до бюджету та визначають рівень зайнятості й доходів українців. Найбільшу перспективу в секторі харчової і переробної промисловості представляють готові до вживання продукти харчування, у тому числі молоко та молочні продукти. Протягом останніх років з втратою основних ринків збуту молочної продукції, Україна активізувала зусилля для пошуку нових міжнародних ринків збуту. На жаль, внутрішній ринок молока та молочної продукції України характеризується низькою купівельною спроможністю населення, що не дає можливості нарощувати обсяги реалізації готової молочної продукції всередині країни. Це, своєю чергою, змушує товаровиробників виходити зі своєю продукцією на нові ринки збуту, здійснюючи адаптацію товарів до вимог та споживчих уподобань тієї країни, до якої планується здійснювати поставки.

Питанням торговельно-економічних відносин у контексті розвитку експортного потенціалу присвячено доволі багато праць вітчизняних і зарубіжних дослідників, зокрема: Л. Абалкіна, В. Андрійчука, Дж. Бхагваті, В. Будкіна, Є. Волкодавової, В.Геєця, Т.Гордєєвої, О. Євдоченко, В. Капіцина, А. Кредісова, В. Леонтьєва, А. Мазаракі, А. Панагарія, Ю. Пахомова, В. Рогачова, Дж. Сакса, М. Сейфуллаєвої, Т. Скорнякової, Дж. Стігліца, Т. Циганкової та інших. Разом з тим, достатньо актуальними лишаються питання розвитку експортного потенціалу харчової промисловості України.

На сьогодні в умовах зростаючої конкуренції на внутрішньому і зовнішньому ринках продовольчих товарів, прискорення перебігу 
інфляційних процесів, постійного зростання вартості енергоносіїв, дефіциту кваліфікованої робочої сили саме питання розвитку експортного потенціалу України стають пріоритетним чинником забезпечення конкурентних переваг для харчових підприємств і галузі в цілому. Існуючі проблеми харчової промисловості зумовлено рядом загальних чинників:

1) в умовах економічної нестабільності домінують короткострокові пріоритети - підприємці орієнтуються на швидку окупність бізнесу з мінімальним ризиком, тоді як впровадження інновацій $\epsilon$ ризикованим, часто потребує більш значних коштів, а ефект від їх впровадження віддалений у часі;

2) значна частка підприємств харчової промисловості відчуває наслідки політичної та економічної кризи, має низьку рентабельність виробництва і не має достатніх коштів для здійснення технікотехнологічного оновлення виробництва. Особливо це стосується малих та середніх підприємств, які самостійно, без державної підтримки не спроможні розгорнути повномасштабний інноваційний процес;

3) дефіцит кваліфікованої робочої сили, здатної працювати на сучасному прогресивному обладнанні та впроваджувати новітні технології, у тому числі в сфері контролю за якістю й безпечністю продукції.

Харчова промисловість України входить до базових секторів економіки, які формують ВВП України, надходження до бюджету та визначають рівень зайнятості й доходів українців. Найбільшу перспективу в секторі харчової і переробної промисловості представляють готові до вживання продукти харчування, у тому числі молоко та молочні продукти. 3 метою розвитку експортного потенціалу України в 2017 році Урядом було затверджено Експортну стратегію України [4] на період 2017-2021 роки, яка визначає стратегічні цілі розвитку торгівлі в короткостроковій перспективі, серед яких: створення умов для розвитку сфер торгівлі задля диверсифікації експорту українських товарів та послуг; підтримка експорту з боку держави, а також підвищення рівня знань та навичок, необхідних підприємствам для здійснення міжнародної торгівлі.

До пріоритетних напрямків реалізації експортного потенціалу харчової промисловості України можна віднести:

1) забезпечення продовольчої безпеки;

2) закріплення поточних торговельних позицій;

3) диверсифікація ринків.

Основними платформами розвитку експортного потенціалу хар- 
чової промисловості України є внутрішній та зовнішній ринки.

Внутрішній ринок. Сьогодні на вітчизняному ринку молока та молочної продукції спостерігається наступне: по факту 73\% виробленого молока забезпечується домогосподарствами, в той час як решта $27 \%$ виробляється аграрними підприємствами. Разом з тим, відбувається скорочення обсягів виробництва молока домогосподарствами в загальній структурі виробництва в динаміці - з 11249 тис. тонн в 2010 році до 10329 тис. тонн в 2017 році. Так, якщо в 2010 році частка виробленого домогосподарствами молока складала 80,3\%, то вже в 2017 році - 73\%. В цілому виробництво молока, починаючи 3 2010 року в Україні скорочується - з 11249 тис.тонн в 2010 році до 10329 тис. тонн в 2017 році (рис. 1). Причинами цього є: несистемна цінова політика основних операторів ринку, які значно зменшують прибутковість та мотивацію для розвитку молочних ферм, сповільнення формації системи дистрибуції та кооперативних сервісів.

Основні проблеми, які обмежують розвиток молочної галузі України зумовлено скороченням обсягів виробництва та рівнем якості молока-сировини, яке надходить до переробників молока. До липня 2018 р базові вимоги до молока регламентувались ДСТУ 3662-97 «Молоко коров'яче незбиране. Вимоги при закупівлі», який діяв ще з 1997 року. Згідно стандарту все молоко залежно від рівня бактеріального забруднення й вмісту соматичних клітин, поділяється на екстра, вищий, перший і другий сорти. Такий поділ молока-сировини на сорти уможливлює здійснення контролю якості промислового молока, яке надходить на переробку.

Молоко-сировина екстра-класу користується підвищеним попитом та коштує дорожче, аніж молоко другого сорту - різниця в середньому сягає двох гривень і більше. Разом з тим, зростає й частка молока екстра-ґатунку в загальному обсязі виробництва.

Якщо в 2013 році частка молока екстра-ґатунку сягала 9,8\%, то в 2017 році на переробку надійшло вже 16,4\% сировини відповідної якості. В 2018 році частка молока екстра-ґатунку, що надходить на переробку, продовжує зростати. Так, на початку 2018 року вона становила $15,5 \%$ і ближче до кінця року зросла до $21 \%$. Варто зауважити, що 50\% з усього молока ґатунку «екстра» в Україні - вироблено господарствами АВМ. Разом з тим, саме молоко екстра-класу $є$ базою для виробництва молочних продуктів, призначених для експорту. У липні 2018 року ДСТУ 3662-97 було змінено на ДСТУ 3662:2015 «Молоко-сировина коров'яче. Технічні умови», з тим, щоб привести державні стандарти України до рівня ЄС. 


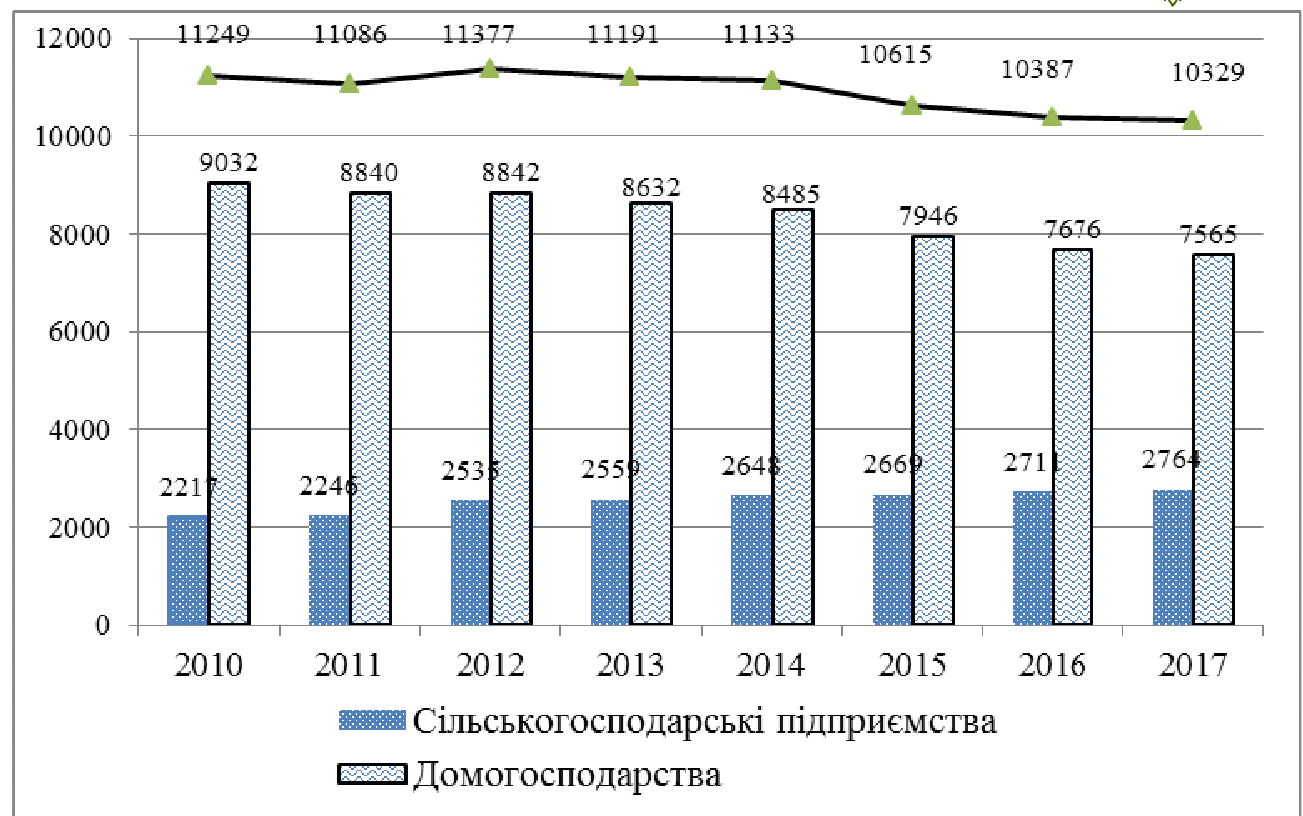

Рис. 1. Виробництво молока в Україні, тис. тонн Джерело: [2; 4]

Такі зміни насамперед спрямовані на захист споживача - безпеку та якість молочної продукції. Разом 3 тим, стандарт ДСТУ 3662:2015 2018 року спрямовано як на підвищення вимог до якості молока, так і на врегулювання використання молока другого сорту. Передбачається, що використання молока другого сорту для технологічних процесів виробництва харчових продуктів буде обмежено, проте дозволено у виробництві нехарчових продуктів, зокрема, кормів для тварин та казеїну. Не зважаючи на це, закупівля молока у господарств населення буде продовжуватися. Базові рекомендації для господарств населення 3 гігієни виробництва молока сформовано Держпродспоживслужбою спільно з Швейцарсько-Українським проектом SAFOSO. На думку експертів, для невеликих господарств оптимальним способом підвищення рівня якості молока може стати кооперація. Адже тоді можна спільно закуповувати й використовувати обладнання, організовувати збут, забезпечувати ветеринарний догляд. До речі, на сьогодні через кооперативи реалізується незначна частка молока, хоча потенціал кооперації величезний.

Впровадження кожного наступного кроку із зміни вимог до якості молока має супроводжуватися аналізом розвитку ринку та ефективності державної підтримки. Кінцева мета - поступове приведення вимог до якості молока-сировини до більш високих норм стандарту 100/400, яким регламентуються порогові значення, за яких 
молоко допускається до переробки в країнах ЄС. Ключовими показниками якості молока-сировини згідно стандарту 100/400 являються: кількість умовних одиниць мезофільних аеробних і факультативно анаеробних мікроорганізмів на один кубічний сантиметр (100 в молоці екстра-ґатунку), кількість соматичних клітин в одному кубічному сантиметрі молока (400 тисяч в молоці екстра-ґатунку) [3].

Зовнішні ринки. В 2014 році вітчизняний ринок відчув економічну кризу через ембарго Росії. Частина експортерів була змушена переорієнтовуватися на країни Азії та СНД. Однак не зважаючи на це, протягом 2014-2016 років відбулось скорочення експорту молока та молочної продукції на 62\% з 511988 млн дол США в 2013 році до 194731 млн дол США в 2016 році. Протягом 2016-2017 років згідно даних аналітичних досліджень Асоціації виробників молока, спостерігається поступове нарощення експорту вітчизняних молочних продуктів до 332676 млн дол США. Виручка від експорту 2017 року в 1,7 рази перевищує відповідне значення 2016 року, що дозволило Україні стати нетто-експортером молочної продукції. Натомість імпорт молока та молочної продукції протягом 2014-2017 років суттєво скоротився з 212869 млн дол США в 2013 році до 66275 млн дол США в 2017 році. Якщо до 2014 року імпорт сира та кисломолочних продуктів здійснювався переважно з країн ЄС і РФ («Данон»), то зараз поставки з Росії практично припинилися, а з країн ЄС - надходять у незначних обсягах. Динаміку експорту та імпорту молока і молочної продукції України протягом 2012-2017 років представлено на рис. 2.

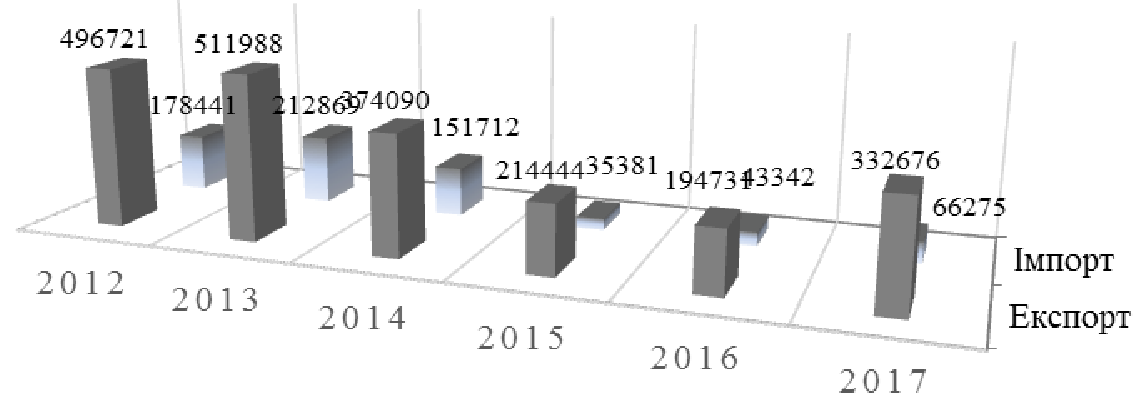

Рис. 2. Динаміка експорту та імпорту молока і молочної продукції України протягом 2007-2017 років, млн дол США

Джерело: [2; 4]

Офіційно доступ до ринку ЄС для молочної продукції України було відкрито 11 січня 2016 року. Тоді перші 10 українських виробників отримали дозвіл на експорт молочної продукції на ринок $Є С$. 
Станом на жовтень 2018 року, кількість затверджених експортерів 3 України зросла до 21. Офіційно доступ до ринку ЄС для молочної продукції України було відкрито 11 січня 2016 року. Тоді перші 10 українських виробників отримали дозвіл на експорт молочної продукції на ринок ЄС. Станом на жовтень 2018 року, кількість затверджених експортерів з України зросла до 21. До переліку компаній, які отримали дозволи експортувати до ЄС увійшли наступні [11]: ТОВ «Лоостдорф», ТОВ «Ласунка», ТОВ «Молочний дім», ПАТ «Дубномолоко», ПАТ «Житомирський маслозавод», ДП ПАТ «Яготинський завод масла», ПАТ «Лактіаліс-Миколаїв», ТОВ «ГАДЯЧСИР», ТОВ «Данон Дніпро», Канівське відділення ТОВ «Клуб Сиру», ПАТ «Вінницький молочний завод «РОШЕН»», ПП «Росс» Філія «Роменський молочний комбінат», ТОВ «Капсуляр», ПАТ «Маслозберігаючий комбінат Золотоноша», ПП Консалтингова фірма «Прометей» Філія «Мена Сир» та інші.

Окрім наведених вище тенденцій варто зазначити, що впродовж останніх років розширилась географія експорту. Основними споживачами української молочної продукції в 2016-2017 роках були - Польща, Нідерланди, Фінляндія. Окрім ринків ЄС Україна активно почала виходити на ринки, які належать до азійського та африканського регіонів. У 2017 році вітчизняними операторами ринку поставки масла здійснювалися до Марокко (20,9\%), Туреччини (18,7\%), Китаю (46\%). Новою країною-партнером для України в 2017 році став Катар - найбільший покупець молока та вершків - 32\% всього експорту молочної продукції 2017 року. Експорт згущених продуктів та сухої сироватки вітчизняні оператори здійснюють, успішно диверсифікуючи напрямки з країн СНД до країн Азії та Африки. Експорт сухого незбираного молока в 2017 році забезпечили вітчизняні оператори ринку - «Вінницький молочний завод «Рошен»» (15\%) і по 42 тонни - ЗАТ «Куп'янський МКК» та ТОВ «Мілкіленд» [1]. Головними експортерами сирів з України в 2017 році були «Комо Експорт» (19\%), «Клуб Сиру» (17\%), «Бель Шостка Україна» (13\%), «Лакталіс Україна» (15\%), «Мілкіленд Інтермаркет» (7\%). Загальна частка їх експорту склала понад 70\%. Лідерами із закупівлі українського сиру в 2017 році стали Казахстан, куди відправили 3,734 тис. тонн (15,7 млн дол США), Молдова - 2,590 тис. тонн (7,640 млн дол США) та Єгипет - 0,989 тис. тонн (3,643 млн дол США).

На думку експертів, криза, яка виникла після втрати російського ринку збуту, поступово проходить. Додаткові обмеження щодо вибору торговельних партнерів диктує відносно короткий термін придатності переважної більшості молочних продуктів. Разом з тим, 
продукція має відповідати вимогам з точки зору якості й безпечності, прийнятими в країні-імпортері.

Експорт молочної продукції з України до країн $€ С €$ відкритим і безмитним у межах квот за умови наявності сертифікатів, які підтверджують якість й безпечність харчової продукції. Відповідно до умов Преференцій в рамках вільної торгівлі між Україною та ЄС (далі ПВЗВТ) ставка ввізного мита ЄС для частини молочних продуктів групи 04, у тому числі сирів всіх видів, кисломолочного сиру, молочної сироватки, були зменшені до 0\% [6]. Встановлення безмитних тарифних квот не означає заборону на експорт понад квоти. Українські компанії можуть без обмежень постачати товари і понад тарифну квоту, проте ці обсяги підпадають під загальний режим імпорту в ЄС. Тобто експорт в межах квоти обкладається митом 0\%, експорт понад квоту - ввізним митом, визначеним Митним тарифом ЄС. Адміністрування тарифних квот для експорту в ЄС здійснюється через систему імпортних ліцензій за принципом «перший прийшов-перший обслуговується» (перероблені молочні та перероблені масляні продукти) [6].

Протягом 2016-2017 років українські експортери найбільш активно використовували безмитні тарифні квоти на вершкове масло, молочні пасти та сухе молоко. Зокрема, у 2016 році тарифну квоту на вершкове масло та молочні пасти використано на 46\%, на сухе молоко - на 30\%. У 2017 р. розпочалося також використання безмитної квоти на молоко, вершки, згущене молоко та йогурти. Крім того, почали здійснюватися поставки молочної сироватки та сирів, до яких тарифні квоти не застосовувалися.

3 метою отримання преференційного доступу на ринок ЄС у рамках ПВЗВТ операторам ринку необхідно підтвердити походження товару з України та отримати сертифікат EUR.1. Разом з тим, при ввезенні молока та молочної продукції до країн ЄС необхідно дотримуватися правил, що гарантують їх безпечність. У вітчизняній практиці управління якістю й безпечністю харчової продукції здійснюється на основі ДСТУ 4161-2003 «Системи управління безпечністю харчових продуктів. Вимоги», ДСТУ ISO 22000:2007 «Системи управління безпечністю харчових продуктів. Вимоги до будь-яких організацій харчового ланцюга», Наказу Міністерства аграрної політики та продовольства України № 590 «Вимоги щодо розробки, впровадження та застосування постійно діючих процедур, заснованих на принципах Системи управління безпечністю харчових продуктів (ХАССП)», Наказу Міністерства економічного розвитку № 1356 ДСТУ-H CAC/RCP 1:2012 «Продукти харчові. Настанови щодо загальних принципів гігієни» (CAC/RCP 1-1969, Rev. 4-2003). 3 метою гармонізації законодавства 
країни та ЄС у сфері безпеки та якості харчових продуктів в Україні було впроваджено: 1) базові принципи і вимоги безпечності харчових продуктів та кормів - згідно Регламентів ЄC № 178/2002, № 852/2004, № 854/2004; 2) заходи, пов'язані з державним контролем у сфері санітарних та фітосанітарних заходів - згідно Регламентів ЄC № 853/2004, № 882/2004, № 854/2004; 3) заходи з маркування - згідно Регламенту ЄС № 1169/2011 та ін.

Європейські замовники можуть також вимагати від виробника наявності сертифікату відповідності певному міжнародному стандарту безпечності харчових продуктів згідно контракту, зокрема: ISO 22000, FSSC 22000, BRC, IFS [6]. Наразі ці сертифікати не $\epsilon$ обов'язковими для ввезення на територію $Є С$, проте вони часто $€$ необхідною умовою для реалізації продукції в ЄС.

Позиції України в умовах глобалізації та активізації інтеграційних процесів визначаються насамперед ії здатністю та можливістю створювати умови для постійного нарощування національного експортного потенціалу. Звісно, його реалізація залежить від багатьох внутрішніх та зовнішніх факторів. На рис. 3 представлено узагальнення результатів проведеного на основі досліджень стану розвитку молочної промисловості SWOT-аналізу сильних та слабких сторін галузі, можливостей і загроз ії розвитку в умовах активізації інтеграційних процесів.

\begin{tabular}{|c|c|}
\hline $\begin{array}{l}\text { Сильні сторони: } \\
\text {-достатньо великий внутрішній ринок; } \\
\text {-наявність значного природно- } \\
\text { ресурсного потенціалу для розвитку } \\
\text { сировинної бази; } \\
\text { "висока інвестиційна привабливість } \\
\text { галузі; } \\
\text { - наявність підприємств, здатних ефек- } \\
\text { тивно конкурувати на внутрішньому та } \\
\text { зовнішньому продовольчих ринках; } \\
\text {-висока довіра споживачів до молочної } \\
\text { продукції вітчизняного виробництва }\end{array}$ & $\begin{array}{l}\text { Можливості: } \\
\text { - зростання молочної продуктивності } \\
\text { худоби, нарощення обсягів виробництва } \\
\text { молока «екстра-класу», кооперація не- } \\
\text { великих господарств; } \\
\text { - покращення контрольних механізмів } \\
\text { якості й безпечності молочної продукції; } \\
\text { - диверсифікація торговельних пото- } \\
\text { ків і максимальна реалізація експорт- } \\
\text { ного потенціалу галузі; } \\
\text { - відкриття доступу до продовольчих } \\
\text { ринків ЄС; } \\
\text { - розширення географії експорту про- } \\
\text { дукції за рахунок азійського та афри- } \\
\text { канського ринків; } \\
\text { - поступове поширення на вітчизня- } \\
\text { ний агропромисловий сектор міжнаро- } \\
\text { дних правил торгівлі, страхування, кре- } \\
\text { дитування, інвестування }\end{array}$ \\
\hline
\end{tabular}




\begin{tabular}{|l|l|}
\hline \multicolumn{1}{|c|}{ Слабкі сторони: } & \multicolumn{1}{c|}{ Загрози: } \\
- кризовий стан сировинної бази; & - обмежена ємність внутрішнього рин- \\
с низька концентрація виробництва & ку продовольства, обумовлена низькою \\
сирого молока в сільськогосподарських купівельної спроможністю населення; \\
підприємствах; & - нестабільні конкурентні позиції віт- \\
- низькі темпи техніко-технологічного & чизняної продукції на зовнішніх ринках \\
оновлення виробництва; & через незавершення процесів адаптації \\
- ризики збільшення виробничих ви- & до європейських вимог щодо якості й \\
трат через зростання зношеності техні- & безпечності харчової продукції; \\
ки, переважання використання заста- & - скасування спеціального режиму ві- \\
рілих технологій; & дшкодування ПдВ \\
- дефіцит кваліфікованої робочої си- & \\
ли, здатної працювати на сучасному \\
прогресивному обладнанні та впрова- \\
джувати новітні технології, у тому числі \\
в сфері контролю за якістю й безпечніс- \\
тю продукції; \\
- неспроможність значної частки ма- \\
лих і середніх підприємств застосову- \\
вати сучасні системи контролю за якіс- \\
тю й безпечністю продукції; \\
- недостатня розвиненість виробничої \\
та логістичної інфраструктур
\end{tabular}

Рис. 3. SWOT-аналіз молочної промисловості України в умовах активізації інтеграційних процесів Джерело: розроблено автором на основі [7; 9]

За результатами SWOT-аналізу молочної галузі України, можна ідентифікувати розвиток українського молочного сектору як такий, що досить активно розвивається та має всі шанси в найближчій перспективі увійти в п'ятірку країн, які динамічно розвивають молочний напрямок. У цілому вдосконалення законодавства України в сфері продовольчої безпеки, його наближення до законодавства ЄС та вимог СОТ має стати стимулом для розвитку міжнародної торгівлі, активізації участі України в забезпеченні міжнародної продовольчої безпеки.

Висновки. Одним із найважливіших напрямів розвитку експортних можливостей національної економіки $€$ експортний потенціал харчової промисловості України. До пріоритетних напрямків реалізації експортного потенціалу харчової промисловості України відносяться: забезпечення продовольчої безпеки; закріплення поточних торговельних позицій; диверсифікація ринків. На рівні держави - це виробництво повноцінної й безпечної молочної продукції; забезпечення максимального зберігання харчової якості та зниження втрат біологічної цінності молочної продукції; формування удосконаленої 
нормативно-методичної бази державного нагляду за якістю й безпечністю молочної продукції і продовольчої сировини, контролю за виробництвом. На міжнародному рівні - це дослідження традиційних і пошук нових ринків збуту, диверсифікація ринків збуту, збільшення кількості експортних позицій готових харчових продуктів.

1. Аграрний 2017-й: рік приросту молочної галузі. URL: http://agravery.com/uk/posts/show/agrarnij-2017-j-rik-rostu-molocnoigaluzi. (дата звернення: 15.05.2019). 2. Вісник молочників - 2018. URL: http://www.ukrmolprom.kiev.ua/ua/analitika/shchomisyachna-analitika. (дата звернення: 15.05.2019). 3. Державна служба статистики України. Офіційний сайт. URL: http://www.ukrstat.gov.ua/. (дата звернення: 15.05.2019). 4. Експортна стратегія України. URL: https://www.ukrinform.ua/rubriceconomy/2410968-eksportna-strategia-ukraini-mert-pocav-drugij-etaprozrobki.html. (дата звернення: 15.05.2019). 5. Пропозиції до плану першочергових дій 3 розвитку промисловості України. URL: https://www.uifuture.org/publications/news/22080-plan-po-razvitiupromyslennosti-ukrainy-doklad-uif-dla-minekonomiki-2017. (дата звернення: 15.05.2019). 6. Про схвалення Концепції Державної цільової програми розвитку аграрного сектору економіки на період до 2020 року : Розпорядження Кабінету Міністрів України від 30 грудня 2015 р. № 1437-р. База даних «Законодавство України»/BP України. URL: https://www.kmu.gov.ua/ua/npas/248907971. (дата звернення: 15.05.2019). 7. Рамкова програма співробітництва для України на 2015-2019 роки. URL: http://www.fao.org/3/a-bp567o.pdf. (дата звернення: 15.05.2019). 8. Стратегія розвитку аграрного сектору економіки на період до 2020 року : Розпорядження Кабінету Міністрів України від 17 жовтня 2013 р. № 806-р. База даних «Законодавство України» / BP України. URL: http://zakon.rada.gov.ua/laws/show/806-2013-\%D1\%80. (дата звернення: 15.05.2019).

\section{REFERENCES:}

1. Ahrarnyi 2017-y: rik pryrostu molochnoi haluzi. URL: http://agravery.com/uk/posts/show/agrarnij-2017-j-rik-rostu-molocnoigaluzi. (data zvernennia: 15.05.2019). 2. Visnyk molochnykiv - 2018. URL: http://www.ukrmolprom.kiev.ua/ua/analitika/shchomisyachna-analitika. (data zvernennia: 15.05.2019). 3. Derzhavna sluzhba statystyky Ukrainy. Ofitsiinyi sait. URL: http://www.ukrstat.gov.ua/. (data zvernennia: 15.05.2019). 4. Eksportna stratehiia Ukrainy. URL: https://www.ukrinform.ua/rubriceconomy/2410968-eksportna-strategia-ukraini-mert-pocav-drugij-etaprozrobki.html. (data zvernennia: 15.05.2019). 5. Propozytsii do planu pershocherhovykh dii z rozvytku promyslovosti Ukrainy. URL: https://www.uifuture.org/publications/news/22080-plan-po-razvitiupromyslennosti-ukrainy-doklad-uif-dla-minekonomiki-2017. (data zvernennia: 
15.05.2019). 6. Pro skhvalennia Kontseptsii Derzhavnoi tsilovoi prohramy rozvytku ahrarnoho sektoru ekonomiky na period do 2020 roku : Rozporiadzhennia Kabinetu Ministriv Ukrainy vid 30 hrudnia 2015 r. № 1437-r. Baza danykh «Zakonodavstvo Ukrainy»/VR

Ukrainy.

URL: https://www.kmu.gov.ua/ua/npas/248907971. (data zvernennia: 15.05.2019). 7. Ramkova prohrama spivrobitnytstva dlia Ukrainy na 2015-2019 roky. URL: http://www.fao.org/3/a-bp567o.pdf. (data zvernennia: 15.05.2019). 8. Stratehiia rozvytku ahrarnoho sektoru ekonomiky na period do 2020 roku : Rozporiadzhennia Kabinetu Ministriv Ukrainy vid 17 zhovtnia 2013 r. № 806-r. Baza danykh «Zakonodavstvo Ukrainy» / VR Ukrainy. URL: http://zakon.rada.gov.ua/laws/show/806-2013-\%D1\%80. (data zvernennia: 15.05.2019).

Рецензент: д.е.н., професор Мальчик М. В. (НУВГП)

Popko 0. V., Candidate of Economics (Ph.D.), Associate Professor (National University of Water and Environmental Engineering, Rivne)

\section{EXPORT POTENTIAL OF FOOD INDUSTRY OF UKRAINE}

The article is to identify opportunities for the development of export potential of food industry of Ukraine in conditions of globalization. The study outlines the priority directions of the development of the export potential of the food industry of Ukraine, analyzes the dynamics of volumes of production, exports and imports of milk and dairy products. SWOT-analysis of the domestic dairy industry in the conditions of activation of integration processes was conducted. As a result of investigations it was proved that the priority areas of the food industry export potential of Ukraine in the framework of the Export Strategy of Ukraine in 2017-2021 years include creating conditions for the development of trade in order to diversify export of Ukrainian goods and services; Export is supported by the state, and to improve the knowledge and skills needed for industrial enterprises of international trade. The methodological principles of implementing export potential include food security; consolidation of current trading positions; diversification of markets. The implementation of the export strategy at the state level involves the production of complete and safe dairy products; the impossibility of bacterial, chemical and physical contamination; ensuring the maximum storage of food quality and reducing the loss of biological value of dairy products; formation of an improved normative and methodological base of state supervision on the quality and safety of dairy products and food raw 
materials, control over the production, procurement, supply, transportation, preservation and sale of products, as well as to create conditions for the production of dairy products of guaranteed quality; development of a modern instrumental and analytical framework for controlling the safety of food raw materials and dairy products. Implementations export strategy at international level involves the study of traditional and finding new markets, diversification of markets, increasing the number of export items processed food products.

Keywords: export strategy of Ukraine, the export potential of the food industry, exports of dairy products, market operators.

Попко Е. В., к.э.н., доцент (Национальный университет водного хозяйства и природопользования, г. Ровно)

ЭКСПОРТНЫЙ ПОТЕНЦИАЛ ПИЩЕВОЙ ПРОМЫШЛЕННОСТИ УКРАИНЫ

Определены приоритетные направления развития экспортного потенциала пищевой промышленности Украины. Осуществлен анализ динамики объемов производства, экспорта и импорта молока и молочной продукции. Проведен SWOT-анализ отечественной молочной промышленности в условиях активизации интеграционных процессов.

Ключевые слова: экспортная стратегия Украины, экспортный потенциал пищевой промышленности, экспорт молочной продукции, операторы рынка. 